\title{
Iitrotakalle
}

Der Somniffion fiir bie zmeite Rejung

Deฒ

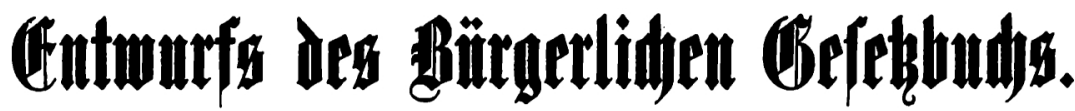

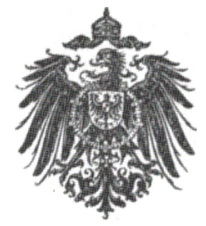

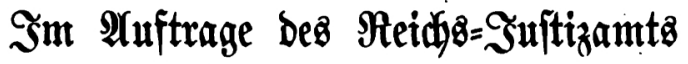

berrbeitet vou

Dr. Xintllew,

Reidjgeriđtšrath a. D.,
Dr. Eraly,

Söniğl. preuß. Sammergeridstకrath.
Dr. Geblyard,

Großj. bab. (Selyeimer Math,

\section{Banb IV.}

Familienredt.

Berlin SW.

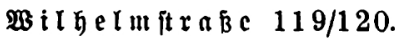

3. Guttentag, Berlagşbudhandlung. 1897. 
